\title{
A Bronze Javelin Point in a Femur from the Necropolis of Pontecagnano (Salerno, Southern Italy, IV Century BC)
}

\author{
Luigi Capasso $^{1}$, Luisa Di Domenicantonio ${ }^{1}$, \\ Aida D'Alessandro ${ }^{2}$, and Caterina Scarsini ${ }^{3}$ \\ 1 Laboratorio di Antropologia - Ministero per i Beni Culturali e Ambientali, Chieti, Italy \\ 2 Istituto di Anatomia Patologica, Università Degli Studi di Pisa, Pisa, Italy \\ 3 Istituto di Antropologia, Università di Firenze, Firenze, Italy
}

(Submitted April 11, 1998; Review sent December 24, 1998; Accepted April 2, 1999)

\begin{abstract}
We describe the right femur of an adult male from grave 4141 of the Pontecagnano Necropolis (Salerno, IV century BC). The cortical surface of the bone is raised around a bronze mass visible on the bone surface at the level of the lesser trochanter at the central area of the anterior surface of the femoral shaft. Around the mass there is new bone, which presents some microscopic evidence of inflammation. X-ray analysis reveals that the mass, which measures $2 \mathrm{~cm}$ in length, is the cone shaped posterior part of a javelin tip, directed upwards, and with the tip folded. Therefore, it appears that the javelin entered near the inguinal plica and struck the anterior surface of the femoral neck from below. This injury could have occurred if the aggressor struck the victim, who was likely on horseback, from below. The roentgenograms also show a well developed reactive bone around the bronze projectile. Both the macroscopic aspects of the injury and its radiographic picture indicate that the victim survived for a considerable time following his unusual injury.
\end{abstract}

Keywords: paleopathology, trauma, bronze point

\section{Introduction}

Traumatic bone lesions are especially interesting to the paleopathologist, because the types of trauma and their frequency are closely related to the life style of ancient populations (Angel, 1974). In particular, traumas produced by aggression often leave clear traces on the skeleton of the victim, and are sometimes the cause of death. Our

Corresponding author: Luigi Capasso

Laboratorio di Antropologia

Via Arniense, 162, 66100 Chieti - Italy

TEL: 0871-33-1526 FAX: 0871-33-0946 E-mail: mssb@unich.it 
interest in these types of traumas, which are always associated with violent life styles, is not just paleopathologic: we are equally interested in attempting to understand the dynamics of the incidents, and determine, from the nature of the osseous lesions, the types of weapons used and how long the victim survived.

\section{Materials and Methods}

In the course of this study we examined the human skeletal remains from tomb 4141 of the Pontecagnano Necropolis (Salerno, Italy), about $70 \mathrm{Km} \mathrm{SE}$ of Naples. The burial is attributable to the Iron Age (IV C. BC), and was excavated in the mid ' 80 s under the direction of L. Cerchiai. For a historical overview of the necropolis and details of the excavations, we refer the reader to the Prof. Edoardo Pardini's thorough anthropological study of the human skeletal remains from Pontecagnano (Pardini and others, 1982). The skeleton in question is well preserved, and belonged to a male, who was about 41 when he died, as is indicated by the combined method (degree of resorption of the ectocranial and endocranial sutures, and tooth wear) developed by Acsadi and Nemeskeri (1970).

\section{Description}

A bronze sliver emerges from the cortex slightly below the linea intertrochanterica, in the median part of the anterior face of the proximal portion of the right femoral shaft of individual 4141 from the Pontecagnano Necropolis, (Figure 1A). Radiographs taken oriented anterio-posteriorly and laterally reveal that the exposed sliver is but a small part of a large projectile, and also reveal its exact position and orientation (Figure 1B, C). The projectile is conical, about $20 \mathrm{~mm}$ long, and $8 \mathrm{~mm}$ in diameter at the base; it is hollow, and its lower free edge has at least one barb. On the basis of its shape and size, it would appear to be a javelin tip. Stereomicroscopic examination of the femur revealed

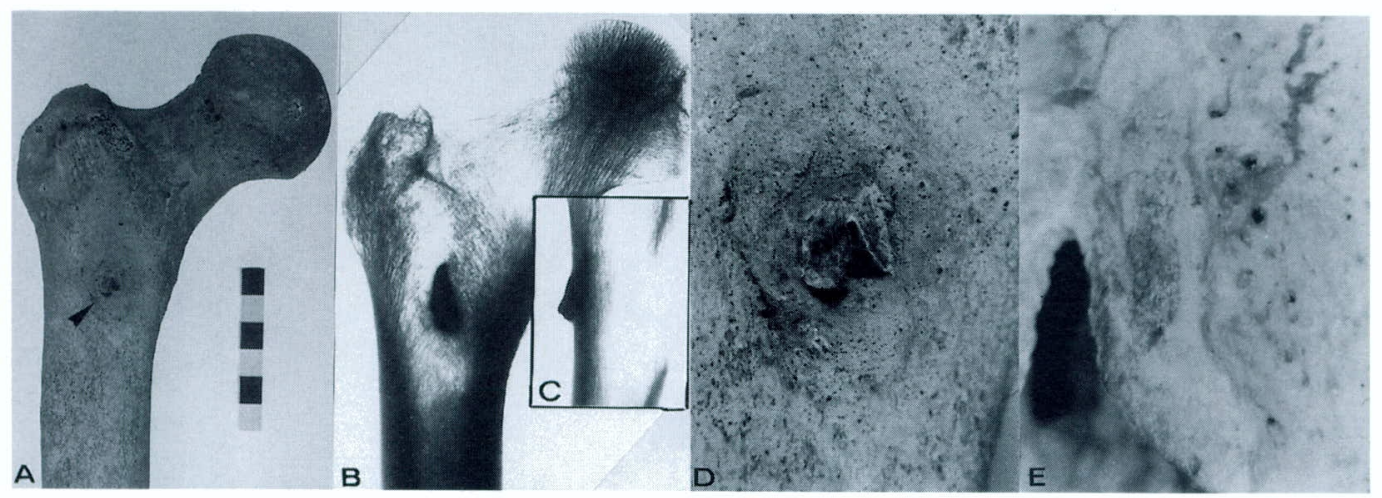

Figure 1 Right femur from grave \#4141 of the Necropolis of Pontecagnano (Salerno): (A) Macroscopic view; (B) Anterior-posterior and (C) lateral radiographic views; (D: 6x; E: 30x) stereo-microscopic views, with evidence of reactive bone around the javelin point. 
a slightly raised rim of reactive bone tissue with a finely porous surface, displaying traces of inflammation around the bronze point (Figure 1D, E), which is almost entirely embedded within the bone.

\section{Discussion}

The radiographs allowed us to determine the path followed by the projectile: it penetrated upwards from below, and slanted slightly from the inside towards the outside. The point penetrated in the vicinity of the inguinal plica, passed through the muscles, and then perforated the femoral cortex, grazing the plica cavum medullare. In the course of its path the point, after penetrating the epidermis, dermis and fascia lata, most likely passed between the $\mathrm{m}$. sartorius, laterally, and the $\mathrm{m}$. adductor longus, medially. It then crossed the muscular fasciae of the $\mathrm{m}$. pectineus, the ileo-psoas, and the $\mathrm{m}$. vastus medialis, grazing the great vessels of "Scarpa's femoral triangle", apparently without injuring them, before penetrating the bone: Indeed, injury to a large artery such as the femoral artery would have caused a major hemorrhage that would in all likelihood have proven fatal. As demostrated by the presence of reactive bone around the bronze point, inflammation should have occurred after the projectile penetrated and destroyed the bone and relevant tissue which remained as reactive bone tissue resulting in the porous condition later.

\section{Comparisons}

Many human skeletal remains with projectiles still lodged in the bones have been described in the paleopathological literature. The cases are numerous and varied, in relationship to the age of the remains (from the Neolithic to the Medieval), their source, and, finally, the nature of the projectiles (metallic or stone). Osseous lesions produced by these sorts of traumas have been observed in the ischium (Etxeberria and Vegas, 1987; Kjaer, 1912), on the internal faces of the sixth, seventh and eighth left ribs (Armendariz and others, 1994), in the cranial vault (Campillo, 1977), and in the left maxilla (Sciulli and others, 1988): in all of these cases the presence of reactive bone tissue around the projectile indicates the victim survived. Other projectiles have been found in the vertebral column (Albrethsen and others, 1976; Armendariz and others, 1994; Bennike, 1985; Manchester and Elmhirst, 1980; Skaarup, 1972), in the maxilla (Armendariz and others, 1994; Becker, 1952; Klindt-Jensen, 1960), in the sternum (Becker, 1952; Vebaek, 1957), in the humerus (Armendariz and others, 1994) and in the orbital cavity (Germanà and Fornaciari, 1992), though in these cases the trauma almost certainly resulted in the death of the victim, as there are no traces of healing on the part of the bone at the sites of the lesions. On the whole, the victims of this type of trauma tend to be juvenile or adult, and male. Projectiles made of flint-stone (Armendariz and others, 1994; Vebaek, 1957; Etxeberria and Vegas, 1987; Sciulli and others, 1988), bone (Becker, 1952), iron and bronze (Campillo, 1977; Kjaer, 1912; Klindt-Jensen, 1960; Skaarup, 1972; Manchester and Elmhirst, 1980; Germanà and Fornaciari, 1992) have been observed. 
They are for the most part arrow heads (Campillo, 1977; Manchester and Elmhirst, 1980; Etxeberria and Vegas, 1987; Albrethsen and others, 1976; Vebaek, 1957; Becker, 1952; Klindt-Jensen, 1960; Skaarup, 1976), though a few are lance heads (Kjaer, 1912).

\section{Conclusions}

The discussed paleopathologic case shows that the projectile penetrated from below, and from the inside towards the outside, just missing the major vessels of the proximal thigh. Given the probable path followed by the projectile, the aggressor must have been underneath the victim, as can occur in the course of a struggle, or below him, for example if the victim was on horseback. The radiologic and microscopic evidence of reaction to the projectile on the part of the bone indicate that the victim survived for a considerable period following the incident.

\section{REFERENCES}

Acsadi G. and Nemeskeri J. (1970) History of human life and mortality. Acadè Kiadò Budapest.

Albrethsen S., Alexandersen V., Petersen E.B., and Balslev Jogersen J. (1976) De levede og dode for 7000 ar siden. Nationalmuseets Arbejdsmark, vol. 93, pp. 5-13. Angel J.L. (1974) Patterns of fractures from Neolithic to modern times. Anthropologie Kozleden, vol. 18, pp. 9-18.

Armendariz J., Irigarai S., and Etxeberria F. (1994) New Evidence of Prehistoric Arrow Wounds in the Iberian Peninsula. International Journal of Osteoarcheology, vol. 4, pp. 215-222.

Becker C.J. (1952) Skeletterne fra Porsmose ved Naestved. Nationalmuseets Arbejdsmark, vol. 69, pp. 25-30.

Bennike P. (1985) Palaeopathology of Danish Skeletons. A Comparative Study of Demography, Disease and Iniury. Akademisk Forlag, Copenhagen.

Campillo D. (1977) Paleopatologia del craneo en Cataluna, Valencia y Baleares. Ed. Montblanc-Martin. Barcelona.

Etxeberria F. and Vegas J.I. (1987) Violent injury in a Bronze age individual of the Basque country (Spain). Journal of Paleopathology, vol. 1, pp. 19-24.

Germanà F. and Fornaciari G. (1992) Trapanazioni, craniotomie e traumi cranici in Italia dalla Preistoria all'Età moderna. Giardini editori e stampatori, Pisa.

Kjaer H. (1912) Et marerkeligt arkaeologisk-antropologisk fund fra Stenalderen. Aarb for Nord Oldk Hist, vol. 3, pp. 58-72.

Klindt-Jensen O. (1960) Var det en yndig tid? Skalk, vol. 3, pp. 9-11.

Manchester K. and Elmhirst O.E.C. (1980) Forensic aspects of an Anglosaxon injury. Ossa, vol. 7, pp. 179-188.

Pardini E., Rossi V., Innocenti F., Stefania G., Fulgaro A., and Patara S. (1982) Gli inumati di Pontecagnano. Archivio per l'Antropologia e l'Etnologia, vol. 112, pp. 281-329. 
Sciulli P.W., Pacheco P.I., and Wymer D.A. (1988) Traumatic pathology in a late prehistoric individual from central Ohio. Journal of Paleopathology, vol. 2, pp. 3-8.

Skaarup J. (1972) Rejsekammeraten. Skalk, vol. 1, pp. 4-9.

Vebaek C.L. (1957) Et usaedvanligt Stenalders Gravfund paa Djursland. Nationalmuseets Arbejdsmark, pp. 75-82.

Handling editor: Suwa Gen 